Research Article

\title{
Analysis of the Distribution and Microscopic Characteristics and Disintegration Characteristics of Carbonaceous Rocks: A Case Study of the Middle Devonian Luofu Formation in Western Guangxi of China
}

\author{
Junhui Luo $\mathbb{D},{ }^{1,2}$ Yong Wu, ${ }^{2}$ Decai Mi, ${ }^{2}$ Qiongyao Ye, ${ }^{2}$ Haifeng Huang, ${ }^{3}$ Zhenchao Chang, ${ }^{3}$ \\ Qinglin Chen, ${ }^{3}$ Tao Zhang, ${ }^{4}$ Guanhua Sun, ${ }^{5}$ Xueheng Wang, ${ }^{6}$ Yu Wang, ${ }^{7}$ and Xianlin Liu ${ }^{2}$ \\ ${ }^{1}$ Guangxi Xinfazhan Communications Group Co., Ltd., Nanning, Guangxi 530029, China \\ ${ }^{2}$ Guangxi Communication Design Group Co., Ltd., Nanning, Guangxi 530029, China \\ ${ }^{3}$ Guangxi Beitou Transportation Maintenance Technology Group Co., Ltd., Nanning, Guangxi 530029, China \\ ${ }^{4}$ Faculty of Engineering, China University of Geosciences, Wuhan 430074, China \\ ${ }^{5}$ State Key Laboratory of Geomechanics and Geotechnical Engineering, Institute of Rock and Soil Mechanics, \\ Chinese Academy of Sciences, Wuhan, Hubei 430071, China \\ ${ }^{6}$ Guangxi Institute of Geological Survey, Nanning, Guangxi 530023, China \\ ${ }^{7}$ Guangxi Road and Bridge Engineering Group Co., Ltd., Nanning, Guangxi 530200, China
}

Correspondence should be addressed to Junhui Luo; jhluo85@hotmail.com

Received 10 May 2020; Revised 13 July 2020; Accepted 12 August 2020; Published 30 August 2020

Academic Editor: Xue Zhang

Copyright (c) 2020 Junhui Luo et al. This is an open access article distributed under the Creative Commons Attribution License, which permits unrestricted use, distribution, and reproduction in any medium, provided the original work is properly cited.

Carbonaceous rock is a special soft rock containing TOC organic carbon 6\% 40\%. In order to reveal the influence of engineering characteristics of carbonaceous rock on the engineering construction, firstly the stratigraphic distribution of carbonaceous Rocks in Guangxi is investigated, and the genetic mechanism and tectonic environment of carbonaceous rocks are discussed. Secondly, the influence of pore microstructure on the disintegration characteristics of carbonaceous rocks is analyzed. The role of geochemical characteristics of carbonaceous rocks (mineral composition, TOC total organic matter content, and type) on engineering properties is revealed. Finally, combined with the distribution, structure, microstructure, and microscopic characteristics of the previous studies, the disintegration mechanism of carbonaceous rocks in water swelling and heat dehydration is discussed. The results are as follows. (1) Carbonaceous rocks in Guangxi are mainly distributed in Devonian, Carboniferous, and Cambrian systems. It is mainly formed in anoxic and reductive deep water basins, slopes, and relatively confined coastal lagoons and swamps. The carbonaceous rocks in the Devonian Luofu formation are most typical. (2) The pores of carbonaceous rocks are divided into mineral pores, organic matter pores, and microfracture, which are mainly mineral pores. The more developed pores in mineral pores are intragranular dissolved pores. Secondly, mineral intergranular pores and a small amount of intergranular dissolution pores and less inner pores. Organic matter porosity increases with the increase of shale organic carbon content and maturity, but the shale porosity and adsorption capacity decrease when shale maturity reaches more than $2.4 \%$. (3) Clay minerals in carbonaceous shale mainly consist of illite and illite/montmorillonite layer, which have water swelling and heat dehydration. The total average value of TOC (total organic matter content) is more than 1\%, which belongs to carbonaceous rocks of medium high grade hydrocarbon source rocks. Organic matter is mainly dominated by type $\mathrm{I}$ and $\mathrm{II}_{1}-\mathrm{II}_{2}$ type with large hydrocarbon generating potential, which is prone to oxidation-reduction reaction and cause rock disintegration. 


\section{Overview}

Carbonaceous rock is a rock containing a large number of dispersed carbonized organic matter. It can be divided into carbonaceous mudstone and carbonaceous shale, as shown in Figure 1. Its engineering properties are poor. It is easy to disintegrate and soften under dry and wet cycles. Meanwhile, according to regional geological data, Guangxi carbonaceous rocks are widely used in engineering construction such as highways, railways and water conservancy, and hydropower projects in the main lithology or intercalation [1]. Due to the obvious disintegration characteristics and environmental sensitivity of carbonaceous Rocks, great hidden dangers and accidents have been caused in engineering construction, which has attracted the attention of various industries. To reduce safety hazards and avoid accidents, slope monitoring and reinforcement or soil improvement should be carried out $[1,2]$. Therefore, a comprehensive and systematic study of carbonaceous rocks is needed from the perspective of engineering.

The petrophysical and geochemical characteristics of carbonaceous shale in Guangxi are different from those of different strata in different ages, but they all have many common engineering characteristics. They are heterogeneous, soft and hard interbedded multilayered structure. The structure of folds, joints, fissures, and faults in the strata are more developed. Carbonaceous rocks have higher initial strength. The lower CBR value and acidity are affected by the natural forces, the sun and the rain. It is very easy to be weathered and disintegrated. Through comprehensive field investigation and rock sample analysis and test results, the main reasons and mechanisms leading to the disintegration of carbonaceous rocks are as follows: the influence of tectonic activities; the water swelling and the dehydration of clay minerals; and oxidation and decomposition of organic matter and reductive minerals.

Carbonaceous rock research at home and abroad is mostly the literature on oil shale and coal. The purpose of finding energy and mineral resources is to analyze the origin distribution, indoor microstructure, organic matter and mineral composition, and carbon isotopic elements and to evaluate the distribution and reserves of resources. The main work is to investigate energy and mineral resources. According to the Guangxi Region geological survey and geological survey and reconnaissance report [4], the main lithology or intercalation of carbonaceous rocks is distributed in various strata units of the Guangxi white mouth to Triassic strata. The relevant stratigraphic grouping needs to be further investigated, verified, consolidated, or revised. The related research is as follows: Guo [5] studied the accumulation conditions of shale gas in the Luofu formation in Tiane-Nandan area, Northwest Guangxi. The rock of the Luofu formation is siliceous mudstone and shale. The average value of shale TOC is $2.36 \%$, the abundance of organic matter is high, and the maturity is high. The organic matter type belongs to the typical mixed kerogen, the upper segment is type II1, the lower part is type II2, and the shale micropores and microfractures develop. The intergranular pores are mainly supported by flake minerals and intergranular pores. The pore size is $3 \mu \mathrm{m} \sim 5 \mu \mathrm{m}$. The dissolution pore is characterized by the dissolution of honeycomb pores on the feldspar surface and the dissolution pores on the surface of carbonate particles. The pores of organic matter mainly appear as sieve pores formed by algal cavity and intergranular pores, and the pore diameter is $20 \mathrm{~nm} \sim 5 \mu \mathrm{m}$. Zhang et al. [6] studied the Luofu formation of the Maude section in Nandan area. It was found that the TOC in the lower part of the Luofu formation was distributed between $1.64 \% \sim 3.69 \%$, with an average value of $2.69 \%$, accounting for $63 \%$ of organic carbon content greater than 2 , accounting for $37.5 \%$ of the total 3 , and TOC of the upper part of the Luofu formation distributed between $0.56 \% \sim 2.96 \%$, with an average value of $1.76 \%$. The relative content is $20 \%$ $35 \%$, the vitrinite and inert group are few, the kerogen type index is $68 \sim 87$, the lower part of the Luofu formation is type I and type II kerogen, and the upper part of the Luofu formation is type II kerogen. The upper and lower two Ro values of the Luofu group indicate that the shale has entered the over mature stage. The main micropores are intergranular pores, mineral dissolution pores, clay mineral pores, mineral intragranular dissolved pores, and palaeo-cavity pores. Wang [7] tried to use aromatics to evaluate the maturity of marine carbonaceous shale organic matter. They measured four shale samples of the Luofu Group and found that vitrinite-like organic matter was small and could be observed for less than 10. The measured reflectivity is only available for reference. The Ro (\%) value is about $2.34 \%$ to $2.78 \%$. Zhang et al. [8] studied the characteristics of the high organic content shale in the Middle Devonian Luofu formation in Guangxi Depression. It is found that the rich organic mud shale in the Luofu Group is similar to other organic rich shales, which are composed of brittle minerals and clay minerals. The organic matter types of the organic rich shale in the Luofu group are mainly type I-II and type 1 . Organic carbon content in the depression is better than $1 \%$, vitrinite reflectance is $2.0 \%$ $3.0 \%$, and organic geochemical characteristics reveal shale gas accumulation. Kun et al. [9] studied the Middle Devonian in the Northwest Guangxi Depression. It was found that the organic matter of dark shale was mainly composed of amorphous and algal bodies, belonging to I type II1 organic matter, with an organic carbon content of $0.29 \%$ to $6.21 \%$, with an average of $1.83 \%$. In the Luofu Group, the average is $1.41 \%$. Dark shale Ro is $1.88 \%$ to $2.84 \%$, the average is $2.5 \%$. The Luofu Group is $2.18 \%$ to $2.83 \%$, and the average $2.56 \%$. Luofu Group has reached the stage of over mature and over mature evolution. Guo et al. [10] studied the sedimentary mud samples of the Middle Devonian Luofu formation in the Tiane-Nandan area, Northwest Guangxi, and he found that the structural background of the shale formation in the Luofu formation is relatively stable. According to the discriminant diagram of trace elements in La-Th-Sc and Th-Co-Zr/10, the Tiane-Nandan area is cast into the La-Th-Sc triangulation map. As shown in Figure 2, the sample points are mainly located in the continental arc and continental margin regions, with the characteristics of passive continental margin. The source rocks of the Luofu Group mainly come from the felsic rocks of the upper crust, and the anomalous variation of delta $\mathrm{Eu}$ is relatively gentle, reflecting that the parent rock is mainly basalt. Sedimentary rocks and granite are mixed together, 


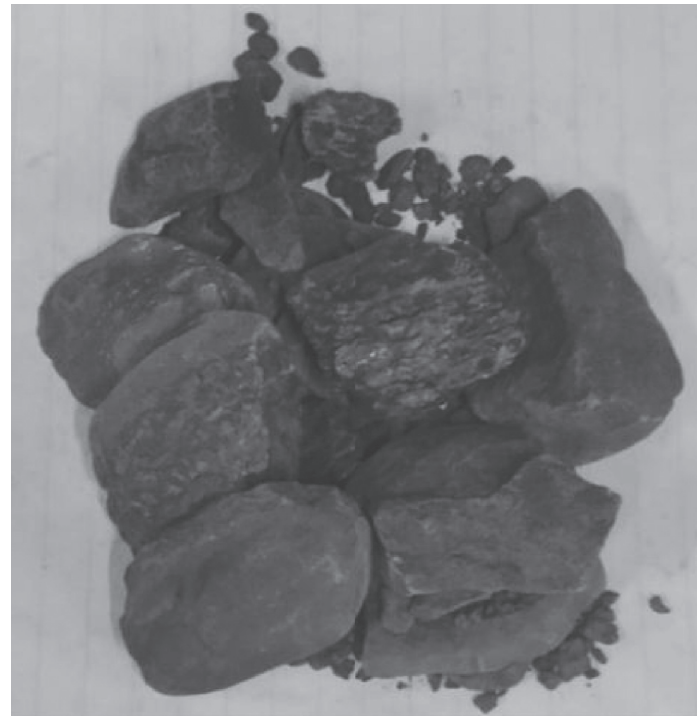

(a)

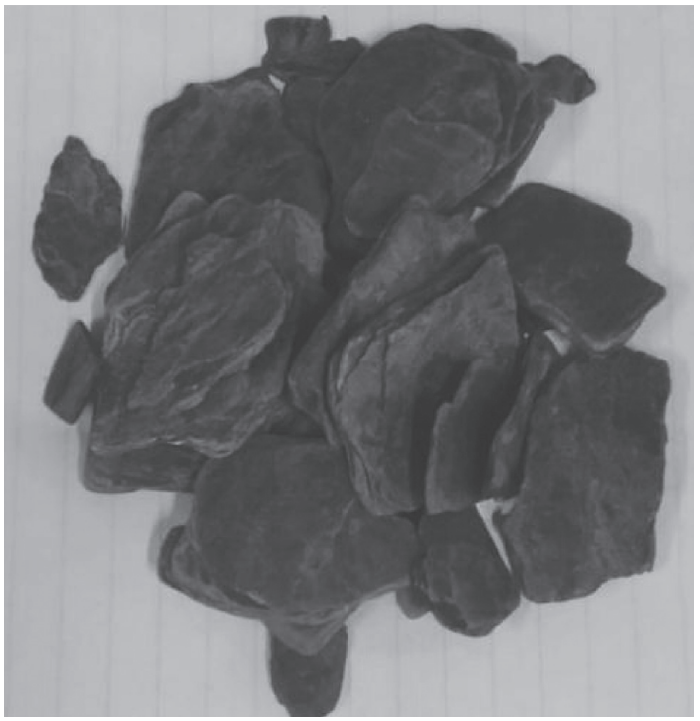

(b)

Figure 1: Main types of carbonaceous rocks. (a) Carbonaceous mudstone and (b) carbonaceous shale.

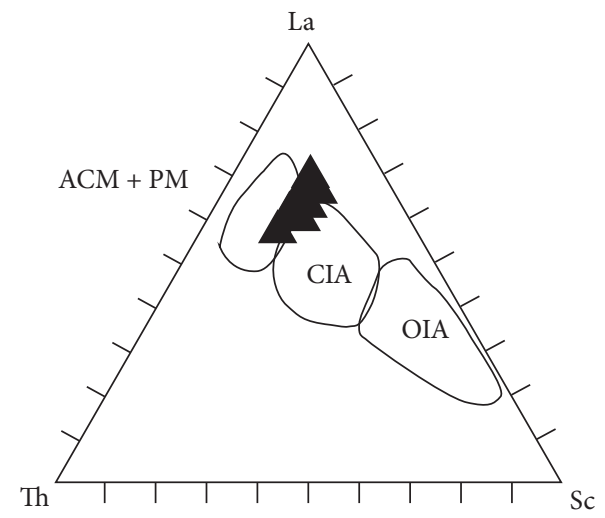

Luofu formation

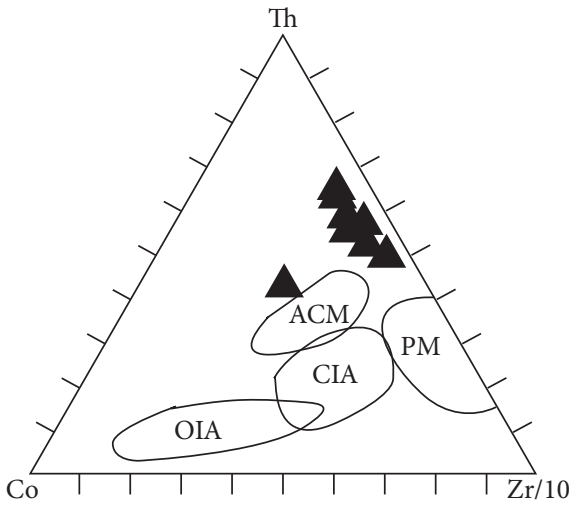

Luofu formation

(a)

(b)

Figure 2: Discriminant map of the tectonic background of the Luofu formation [10] (PM: passive continental margin; ACM: active continental margin; CIA: continental island arc; and OIA: oceanic island arc).

showing the enrichment of light rare earth elements relative to heavy rare earth elements. The black shale source rocks of the Luofu formation in Western Guangxi are studied by Pan et al. [11]. The results show that the abundance of organic matter in source rocks is generally high, and the TOC value is $0.62 \%$ $2.74 \%$, with an average value of $2.12 \%$, which exceeds the hydrocarbon generation threshold $(\mathrm{TOC}=0.2 \%)$. The organic matter of source rocks in Hechi Nandan profile is mainly type I1. Most of the other types are type I.

In the southwest section of Hechi, the value of type III1 Ro is $3.47 \% \sim 3.73 \%$, which is an all-over mature stage. The source rocks of the Luofu formation are mainly from lower aquatic organisms, with the input of terrigenous higher plants, and the sedimentary environment is reduced brackish water marine sedimentary environment.
To sum up, from the aspect of engineering construction, first of all, through data collection and field geological survey, the main distribution horizon, exposed area, and lithological combination characteristics of carbonaceous rocks in Guangxi area were identified. Large scale comprehensive profile measurement and sampling test were carried out in key areas. Secondly, the influence of microscopic characteristics of main minerals and chemical composition, total organic carbon content, and chemical reaction on the characteristics of carbonaceous rock disintegration engineering is studied. The main mechanism and development law of carbonaceous rock disintegration are analyzed. The research results provide theoretical basis and engineering geological research data for engineering personnel and have far-reaching economic and social value 
in improving the safety and quality of engineering construction [12].

\section{The Distribution and Structure of Carbonaceous Rock in Guangxi and Its Influence on Engineering Properties}

2.1. Carbonaceous Rock Formation Distribution. Guangxi is located in the western part of Southern China, China, as shown in Figure 3(a). From east to west, it is bordered by Guangdong, Hunan, Guizhou, and Yunnan. It borders the Beibu Gulf in the south, faces Southeast Asia, and is adjacent to Vietnam in southwest. It is the most convenient access channel in Southwest China. According to the regional geological records of Guangxi, the regional geological survey, special geological survey, and seismic analysis [13], it is revealed that the carbonaceous rocks in Guangxi area are widely distributed in the strata, often as the main lithology or frequently occurring interbeds, and distributed in the different strata of the Qinghai Guangxi white to Triassic Epoch. The main lithologic assemblages and strata thickness of each segment are changed greatly; comprehensive knowledge and field investigation have been used to screen out the main carbonaceous rock formation units [14]. Their general distribution range and main lithological assemblage characteristics are clearly defined. Each group is shown in Figure 3(b): the Qingbai system, the Hetong formation (Qbh); the Sinian Dou Shan Tuo formation $\left(\mathrm{Z}_{2} \mathrm{~d}\right)$; the Cambrian Qingxi formation $\left(\epsilon_{1} q\right)$; the Ordovician Shengping formation $\left(\mathrm{O}_{2} \mathrm{~s}\right)$; the Silurian Liantan group $\left(\mathrm{S}_{1} \mathrm{l}\right)$; the Devonian Tangding formation $\left(\mathrm{D}_{1-2} \mathrm{t}\right)$, and the Luofu formation $\left(\mathrm{D}_{2} \mathrm{l}\right)$; the Carboniferous Luzhai formation $\left(\mathrm{C}_{1} \mathrm{lz}\right)$, the Yingtang formation $\left(\mathrm{C}_{1} \mathrm{yt}\right)$, the Gold group $\left(\mathrm{C}_{1} \mathrm{~h}\right)$, and the Temple group $\left(\mathrm{C}_{1} \mathrm{~s}\right)$; and the Permian Longtan Formation $\left(\mathrm{P}_{3} \mathrm{l}\right)$, the Dalong formation $\left(\mathrm{P}_{3} \mathrm{~d}\right)$, the leader group $\left(\mathrm{P}_{3} l \mathrm{~h}\right)$, and the Triassic stone gun group $\left(\mathrm{T}_{1} \mathrm{~s}\right)$. In Figure 3(b), the pink icon is Denvonian Luofu Formation of the geological map, Figure 3(c) is stratigraphy column of Luofu Formation.

2.2. Influence of Carbonaceous Rock Stratum Structure on Engineering Characteristics. Guangxi is located in the southwestern section of the Yangtze belt and Wuyi-Yun Kai arc basin and has undergone four cycles of tectonic movement, including the "the three fortress movement," "the Caledonian Movement," "the Hercynian Indosinian movement," "the Yanshan movement," "the Himalaya movement," and "the neotectonic movement." A complex geological structure system was formed. Carbonaceous rocks were mainly formed in anoxic and reductive deep water basins, slopes, and relatively confined coastal lagoons and swamps. Sediments were mainly composed of fine-grained argillaceous and silty sand, and the deposition rate was slow in the process of diagenesis. It belongs to tectonic weak layer. These structural weak layers are more prone to produce various kinds of folds (such as Figure 4), fault, joint, cleavage, fissure, and other structural deformation and a series of structural weak faces in previous tectonic movements, providing basic structural geological conditions for the injection of active fluids in later stage of groundwater and strata, and further improving the slip coefficient between strata. The stability of carbonaceous rock slope is affected. In addition, the sudden factors such as sudden rainstorm in carbonaceous rock slope under natural exposure will cause geological disasters such as collapse and landslide along the structural plane with joint and cleavage development [15].

2.3. Lithology Characteristics of Carbonaceous Rocks: A Case Study of the Middle Devonian Luofu Formation in Western Guangxi. Carbonaceous rocks in Guangxi are widely distributed. However, due to their different genetic environments, carbonaceous rocks in different strata are different in composition and lithological characteristics.

2.3.1. Distribution of Carbonaceous Rocks in the Luofu Formation. The typical carbonaceous rock formation is the Devonian Luofu $\left(\mathrm{D}_{2} \mathrm{l}\right)$ in Western Guangxi. It is mainly distributed in Guangxi Nandan five Hechi, Shanglin Binyang, Wuming Taiping Gan Wei, Baise Yang Xu, and Tianlin eight crossing. In the area of Luofu Xiang in Nandan County, the lower carbonaceous rock formation is mainly composed of black horizontal mudstone and marble stone. The upper part consists of thin mudstone and marlite and a few calcareous siltstones. Occasionally, phosphorite nodules and siderite belts occur. From north to the Huang Jiang and Luo Tun areas, the lithology is mainly mudstone, but the rocks contain more silty or calcareous, and some finegrained quartz sandstone appears at the bottom, and the limestone intercalation increases obviously. There are corals and laminar reefs near the Dachang mountain area near the Dachang. From southeast to Hechi, the area of north Xiang and five polders is thin-thick marl, calcareous mudstone, or calcareous mudstone containing marl and mudstone. The lower part of the eight-crossing area in Tianlin county is a thin mudstone in gray black, and the upper part is dark gray black mudstone, siliceous mudstone, fine-grained dolomite, and silt and mudstone. In Shanglin County and Wuming District, the group has an integrated contact relationship with the lower Tangding formation and the overlying GRANJIANG River group. The lithological difference is relatively large on the lateral side. The Lei Huang-Xiang Xian area is a gray thin siliceous rock, and the siliceous rock contains a small amount of siliceous mudstone. The lower part of the lower part of the Ma Tou Bai Shi area is interbedded in the deep gray-gray black thin layer with bioclastic powder limestone and gray-gray thin mudstone.

2.3.2. Stratigraphic Relationship. In the relationship between different strata, the Luofu formation is a series of black mudstone, carbonaceous mudstone, calcareous mudstone, marl and a small amount of sandstone, and siltstone and a small amount of marl. The upper part of the strata is black mudstone or the gray thin layer siliceous mudstone intercalated with the siliceous rocks. As a result, the rift formation 

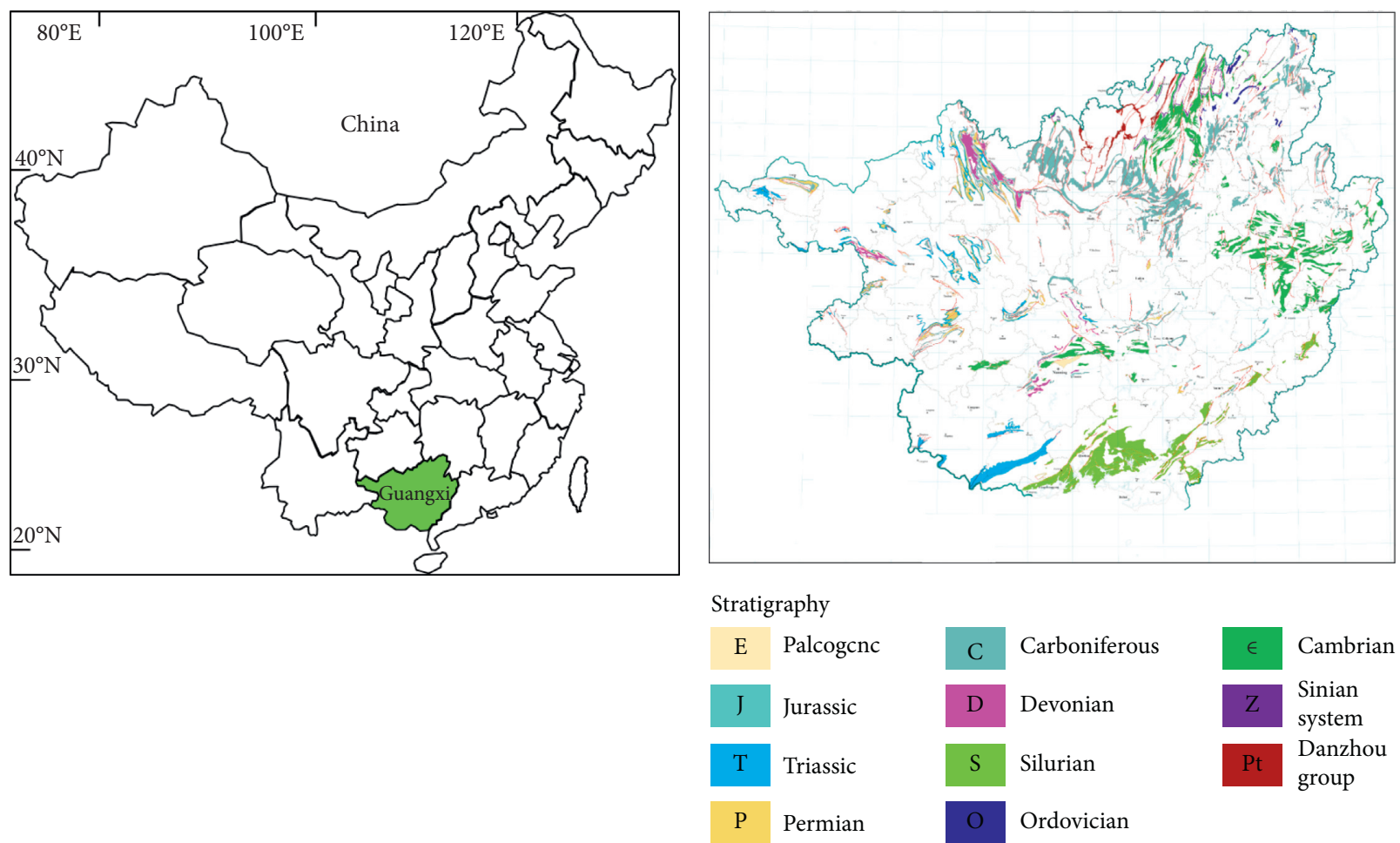

(a)

(b)

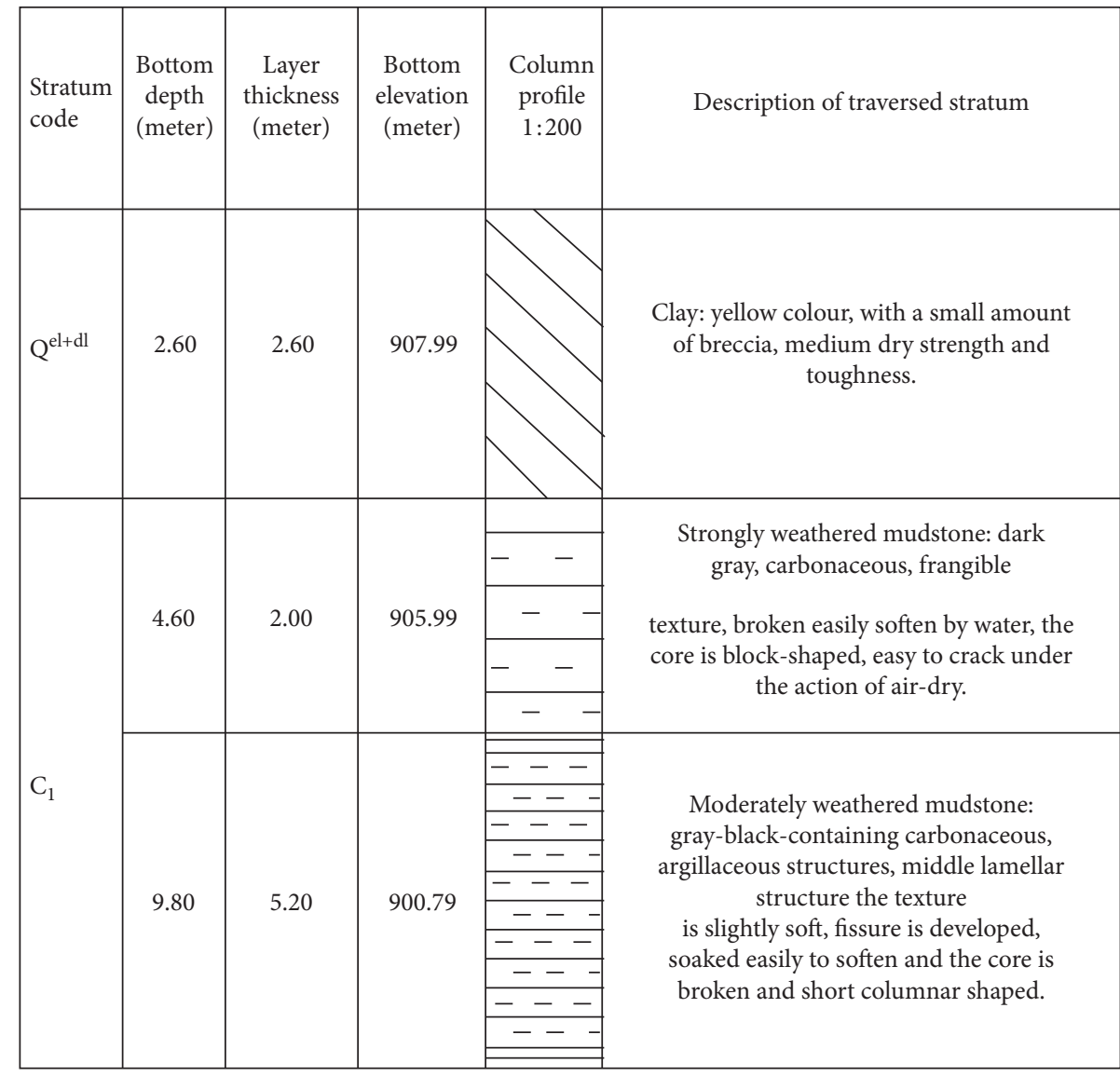

(c)

FIGURE 3: Distribution map of Guangxi and carbonaceous rocks in China. (a) Map of Guangxi, China, (b) distribution map of carbonaceous rocks in Guangxi, and (c) the stratigraphy column of Middle Devonian Luofu formation. 


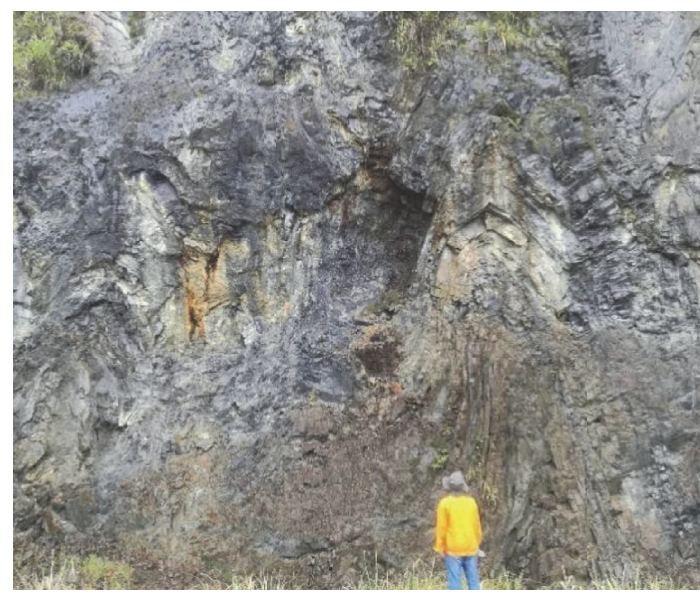

Figure 4: Guangxi carbonaceous siliceous rock fold structure.

is adjacent to the Tangding formation. The carbonaceous rocks in the group are more pure, the thickness is large, the sedimentary thickness is $102 \sim 913 \mathrm{~m}$, and the thickness of the strata is the largest in the Luofu area of the Nandan depression. The developed part of the part of the Bauma sequence is deeper than that of the deep slope facies. The lithology is gray and black carbonaceous mudstone, calcareous mudstone and biotic marl lens, locally cladding tuff, phosphorous tuffaceous gravel bearing mudstone, siliceous shale, siltstone, and quartz fine sandstone. Fossils are developed as coral and Permian reefs in the leading mountain area of Dachang, Bioclones Nowakiaotomari, Viriatellinaguangxiensis, V. minuta, V. multicostata, and fossils such as stronidas, and three species.

2.3.3. Characteristics of Carbonaceous Rocks in the Luofu Formation. According to the on-site investigation, the main lithology of carbonaceous rocks in the Luofu formation is deep gray, black thin middle carbon mudstone, sludge mudstone, calcareous mudstone, carbon-dyed bioclad mudstone, siltstone with very thin layer of silty mudstone (such as Figure 5(a)), middle thin layer fine sandstone, lenticular marlite, Huang Tie-mineralized mudstone cluster (as shown in Figure 5(b)), a small amount of phosphorus nodules, and siderite belts. At the bottom of the group, there are fine sandstone and quartz fine sandstone with $2 \sim 3$ thickness of $15 \sim 30 \mathrm{~cm}$. In the middle part, there are much intercalated limestone, silty microcrystalline limestone, and lenticular marl, and the middle upper siderite belts, phosphorus nodules, calcareous nodules, and pyrite masses are mainly composed of two sulphides of iron. So, pyrite often precipitates sulphides, as shown in Figure 5(c), and iron and manganese nodules are more numerous (as shown in Figure 5(d)). At the same time, carbonaceous rocks have joint and cleavage (as shown in Figure 5(e)), horizontal stratification (as shown in Figure 5(f)), horizontal lamination, sand ripple cross bedding and positive grain bedding, and partial wave stratification, inclusion stratification, collapse structure, sand pillow structure, bottom scour structure, and weak bottom mold structure are found locally. This group is rich in biogenic fossils, with more pliones, ammonite, brachiopod and a few eumacs, three leaf insects, arbor, and bivalves, and occasionally sponges and radiolarian.

\section{Microscopic Pore Structure of Carbonaceous Rock and Its Influence on Engineering Properties}

3.1. Pore Types of Carbonaceous Rocks. Pore system is an important space for gas storage of carbonaceous shale, and also an important channel for fluid migration. Therefore, the types, development characteristics, and relationships of pores have great influence on the stability and swelling capacity of carbonaceous shale in the later stage. The types of pore developed in the sample include 3 types of reservoir space, including mineral pore, organic matter pore, and microfracture (Table 1), see [16], for details.

Mineral pores mainly include intergranular pores, intergranular dissolution pores, intragranular pores, and intragranular dissolved pores. Organic pores belong to pores formed by organic matter in the late thermal evolution process, while microcracks are mainly developed in the laminar development stage and easy to form bedding joints between rigid minerals and plastic minerals [1].

\subsection{Influence of Porosity and Permeability on Engineering} Properties. According to the different locations of mineral crystals and minerals, mineral pores can be divided into four types: mineral intergranular pores, intergranular dissolution pores, intragranular pores, and intragranular dissolved pores.

3.2.1. Intergranular Pore. Intergranular pore is one of the main pore types of carbonaceous shale. It is mainly developed in quartz crystal, feldspar, pyrite, and calcite, which are brittle, well compacted, and intercalated with clay minerals such as illite, kaolinite, montmorillonite, and chlorite. They are triangular, long, and irregular. The diameter of these pores is mostly 1-200 $\mathrm{nm}$. It can be further divided into two kinds: intergranular pore and clay intergranular pore. Among them, the intergranular framework hole is shown in Figure 6. There are pores between the clay minerals and the edge pores of the rigid grains. It is mainly formed between brittle mineral particles, and there is also a distribution between the local clay minerals. Generally, it is generated with the burial depth and diagenesis of carbonaceous shale, similar to the intergranular pores supported by grains in coarse clastic rocks. The morphology of the grain hole is consistent with the outer edge of the grain. Quartz, feldspar, pyrite, calcite, gypsum, and dolomite have some anticompaction effect. These pores can be partly preserved under the conditions of compaction and diagenesis and are mostly triangular.

The clay interlayer pores are mainly developed between the clay soil. When the clay is deposited, flocs are thickly floc, and the intermespores of clay are located between the supporting clay sheets. Because the clay is a plastic mineral, when the clay particles and the quartz and other brittle mineral particles are contacted, due to the different compaction resistance of the two materials, the deformation of the clay and brittle particles will 


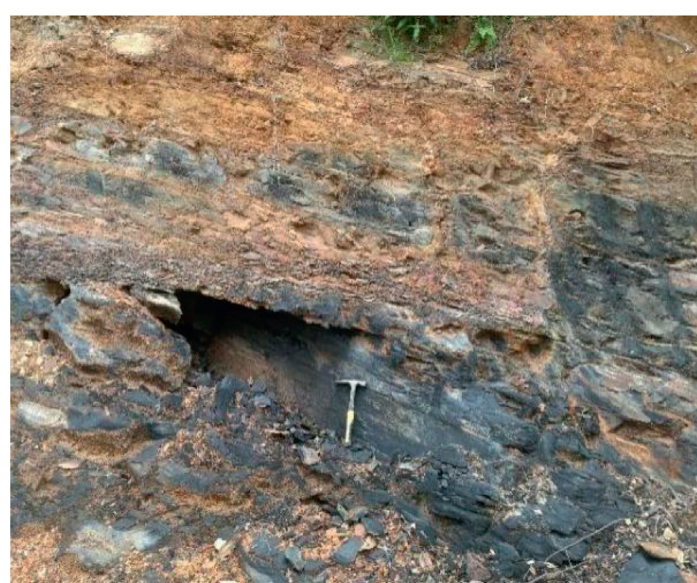

(a)

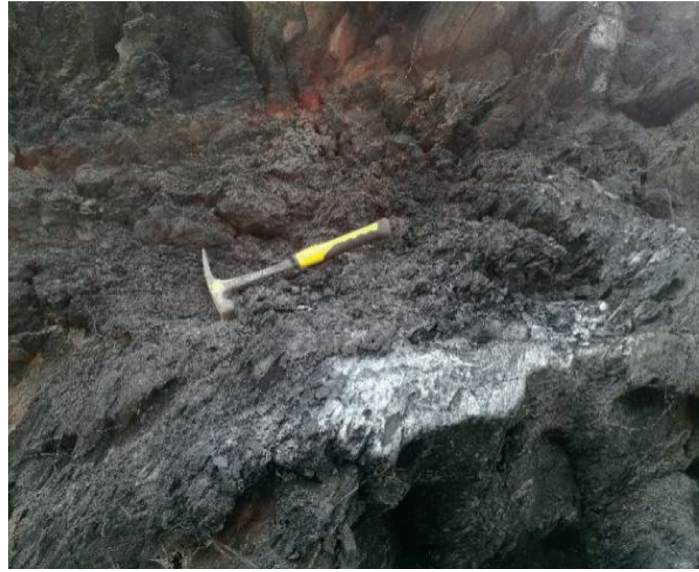

(c)

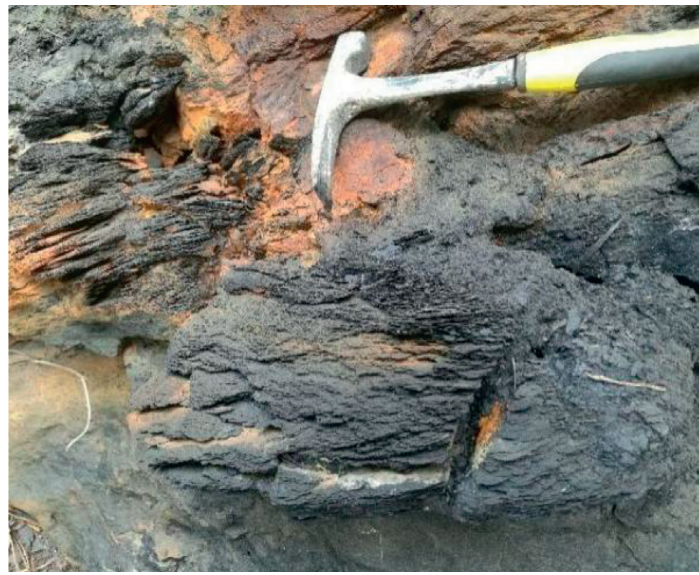

(e)

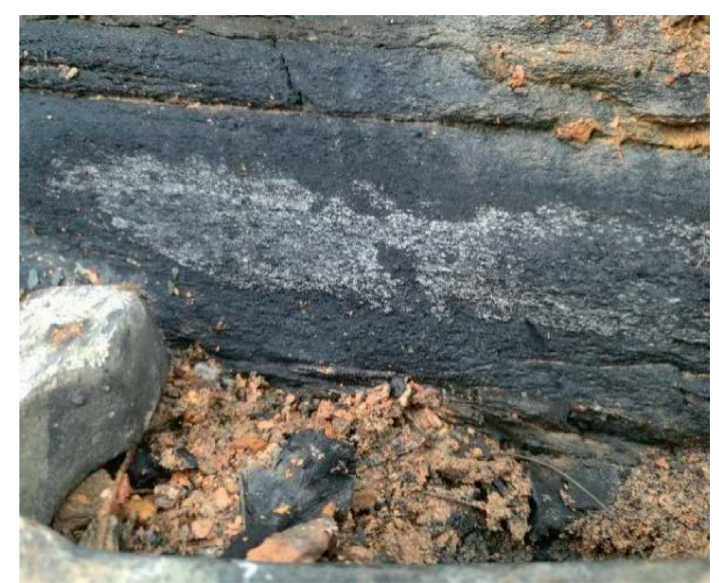

(b)

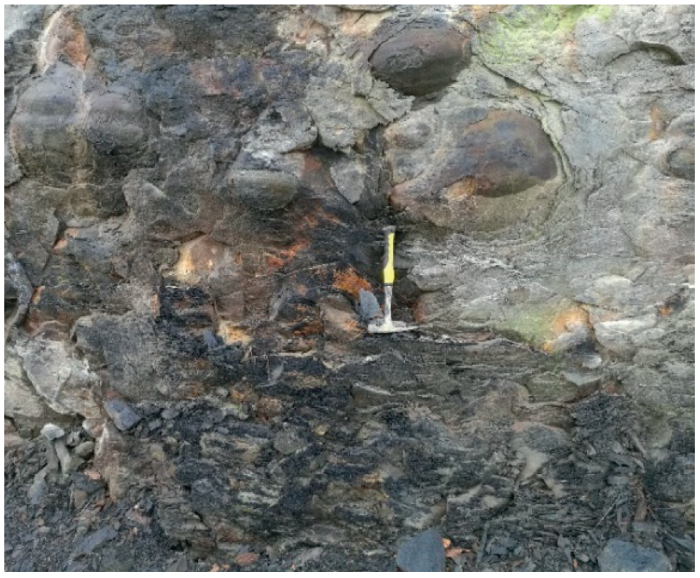

(d)

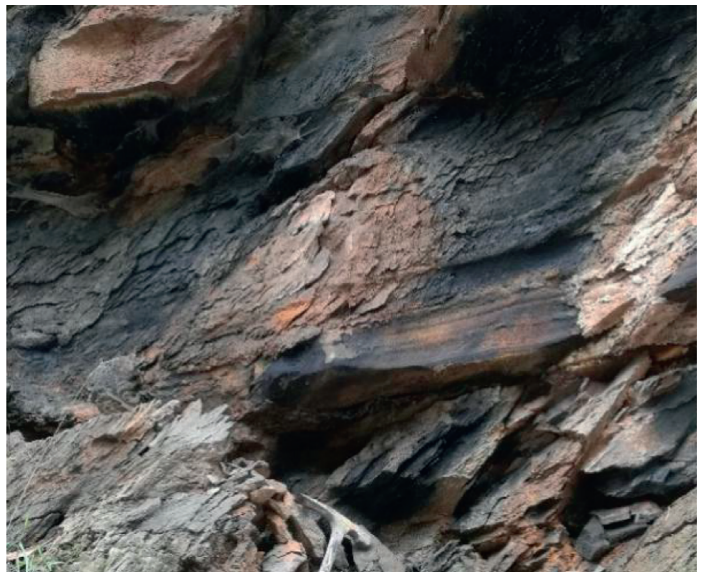

(f)

Figure 5: Field investigation of carbonaceous rocks in the Luofu formation, Western Guangxi province. (a) Combination of silty mudstone and carbonaceous mudstone. (b) Pyrite-enriched layer in carbonaceous mudstone. (c) Iron and manganese nodules in carbonaceous mudstone. (d) Precipitated from semiweathered carbonaceous rocks. (e) Horizontal bedding structure in semiweathered cleavage carbonaceous shale. (f) Carbonaceous mudstone.

produce pores. Clay sheets may also be formed by pores due to compaction, or parallel to clay sheets, or bent into crescent forms (strongly caused by compaction during the diagenetic stage). Intergranular pores occur mainly in the depositional stage. Under special circumstances, the dehydration of clay minerals in the diagenetic stage can also form clay intermespores. There are some intergranular pores formed between clay particles such as illite, kaolinite, and montmorillonite, which have great influence on the stability of carbonaceous rocks. The more intergranular pores are, the easier the carbonaceous rocks are disintegrated. 
TABLE 1: Main pore types of carbonaceous rocks.

\begin{tabular}{|c|c|c|}
\hline Pore type & Features & Form \\
\hline Organic pore & $\begin{array}{l}\text { The pore size of organic matter is generally micron level, and some can } \\
\text { reach nanometer level }\end{array}$ & $\begin{array}{c}\text { Round, oval, long strip and irregular } \\
\text { shape, etc. }\end{array}$ \\
\hline Intergranular pore & \multirow{4}{*}{ The aperture is nanometer and micron level } & Triangle, strip, and irregular shape \\
\hline Intergranular corrosion & & Round, oval, long, triangular, and \\
\hline $\begin{array}{l}\text { pore } \\
\text { Intragranular pore }\end{array}$ & & $\begin{array}{c}\text { irregular } \\
\text { Elliptical, irregular, etc. }\end{array}$ \\
\hline $\begin{array}{l}\text { Intragranular dissolution } \\
\text { pore }\end{array}$ & & Round, oval, irregular, etc. \\
\hline Microfracture & $\begin{array}{l}\text { The width is generally nanometer, and the length is generally micron } \\
\text { level }\end{array}$ & Strip shape \\
\hline
\end{tabular}

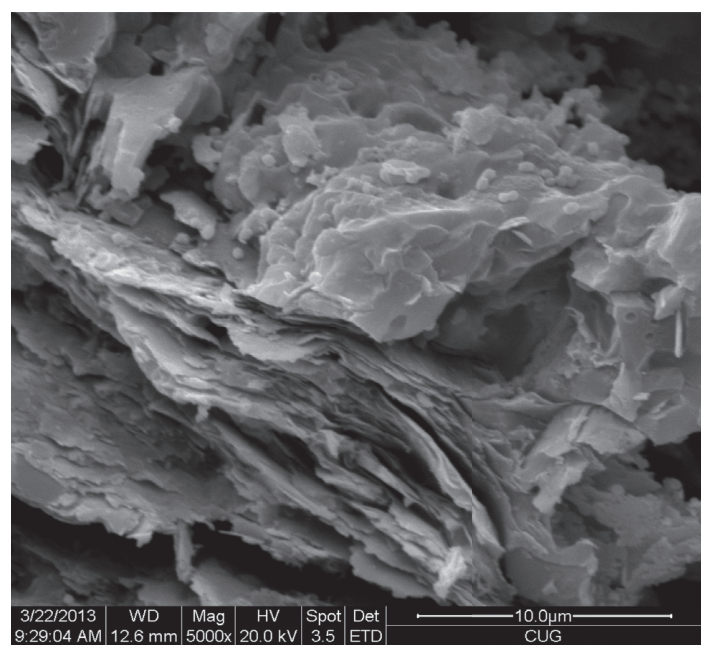

(a)

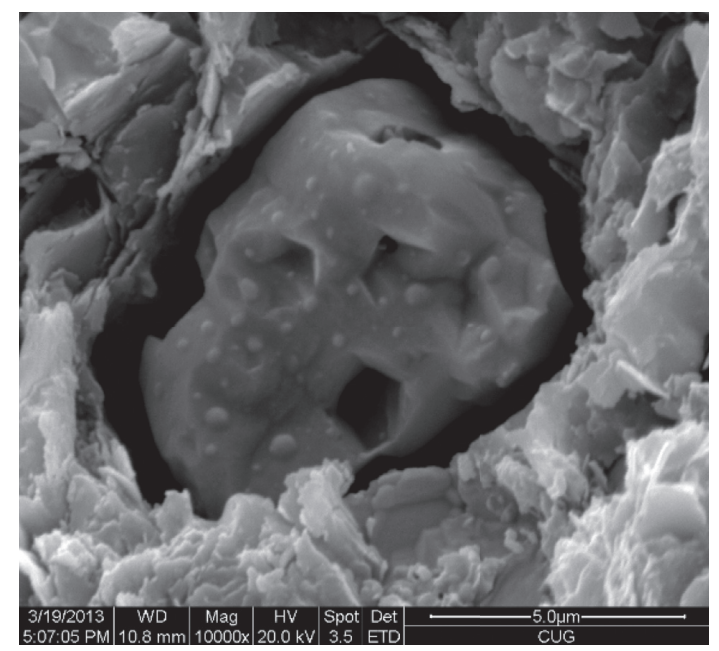

(b)

FIGURE 6: Intergranular pore of carbonaceous rock: (a) intergranular pores and (b) between the clay minerals and the edge pores of the rigid grains.

3.2.2. Intergranular Corrosion Pores. The intergranular dissolution pores, as shown in Figure 7, are mainly formed by secondary dissolution micropores formed by pressure dissolution between calcite and feldspar, and their pores are harbor-shaped, round, oval, elongated, triangular, and irregular. The diameter of pores is generally micron level and connectivity is good. Pores can be filled by calcite and clay cements. The development degree of intergranular dissolution pores is reduced. The development of dissolution pores between grains is more affected by late stage transformation, and the dissolution pores are poorly developed in areas where dissolution is small, otherwise the intergranular dissolution pores develop.

Figure 7 the secondary dissolution pores and fissures developed by carbonaceous shale are mostly dissolved at the interface between joints and minerals, such as between pyrite and clay minerals and between feldspar and quartz minerals. The size of pores is different, and a small number of interstitial pores are found locally, and the edges of individual grains are slightly corroded.

3.2.3. Intragranular Pore. Intragranular pores are mainly developed in pyrite, quartz, calcite, and clay. The shape of

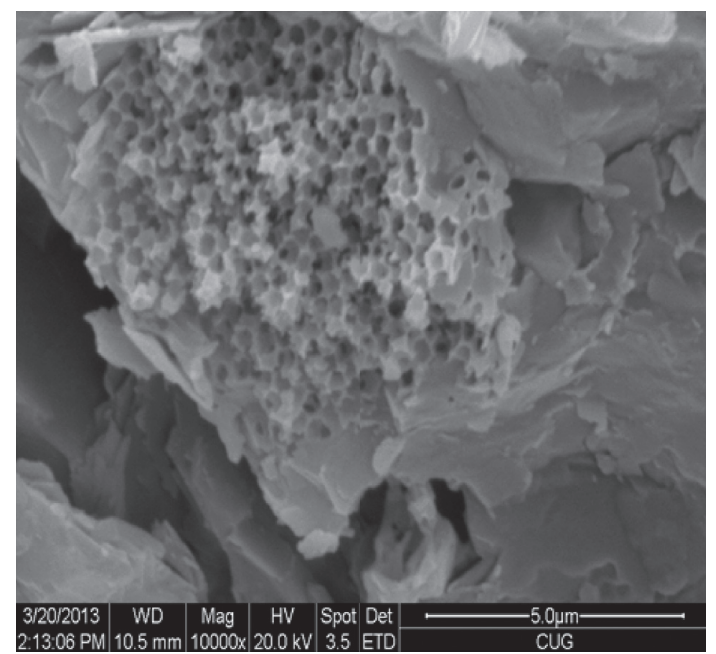

FigURE 7: Intergranular corrosion pores of carbonaceous rocks.

strawberry is as shown in Figure 8. Most of them are caused by diagenesis, which is caused by diagenesis. In addition, the mat-like pores and irregular elongated pores in the clay mineral grains also belong to intragranular pores. They are 


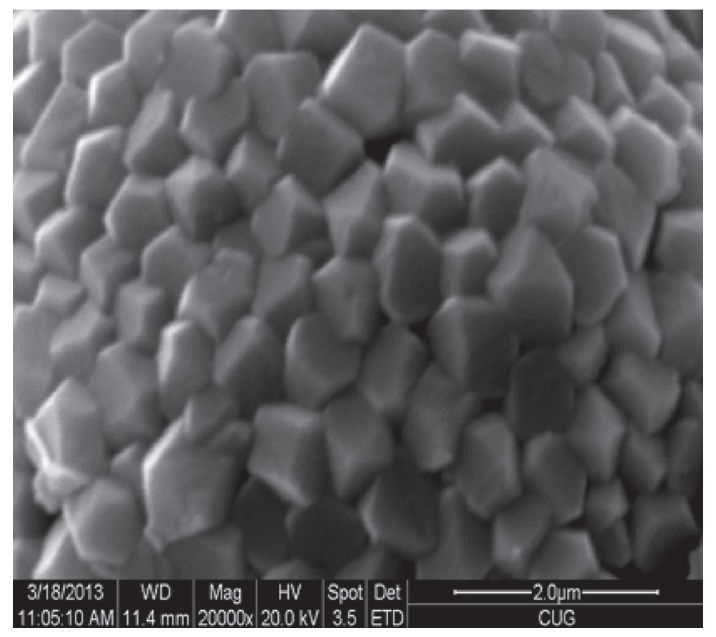

FIgURE 8: Carbonaceous rock strawberry pyrite grain hole.

parallel to the bedding plane, with a width of several tens of nanometers and a longer length. Clay mineral particles are approximately parallel to the bedding plane when they are deposited. Therefore, when there is no interference of brittle particles, the mat-like and linear pores in the clay particles are arranged parallel to the bedding plane.

As shown in Figure 6, the pore shape of strawberry granular pyrite crystal is mostly irregular, which only accounts for a small part of the micropores of the shale, and the development horizon is relatively limited.

3.2.4. Intragranular Dissolution Pore. The dissolution pores of carbonaceous shale are shown in Figure 9; they are mainly found in easily soluble brittle minerals such as calcite, dolomite, feldspar, and phosphate. The dissolution is strong enough to destroy the whole particles. The pores are generally round, elliptical, and irregular. The pore size is generally nanoscale, and the larger one can reach several microns. Moreover, the dissolution often has strong fluid activities. These pores provide space for fluid activities such as groundwater. Later, they tend to have great influence on the weathering and deformation of carbonaceous mudstones. It can be concluded that the larger the dissolution pores are, the more obvious the collapsing property of carbonaceous rocks is.

\subsection{Influence of Organic Matter Pore on Disintegration} Characteristics. Organic matter pores (as shown in Figure 10) are mainly developed in the middle of organic matter grains of carbonaceous shale. They are formed by thermal degradation during the burial process of organic matter, forming a very complex internal network system, which makes the organic matter have larger specific surface area and pore volume. This kind of Kong Xiping surface is round, oval, irregular, and forms complex inner structures such as columnar and caves in space. Tubular pore roaring channels connect nanoscale pores, and some adjacent stomata connect with each other. The edge of the pore is smooth and the outline is clear. Some pore edges are bent, and the pore size of organic matter varies greatly from nanometer to micron.

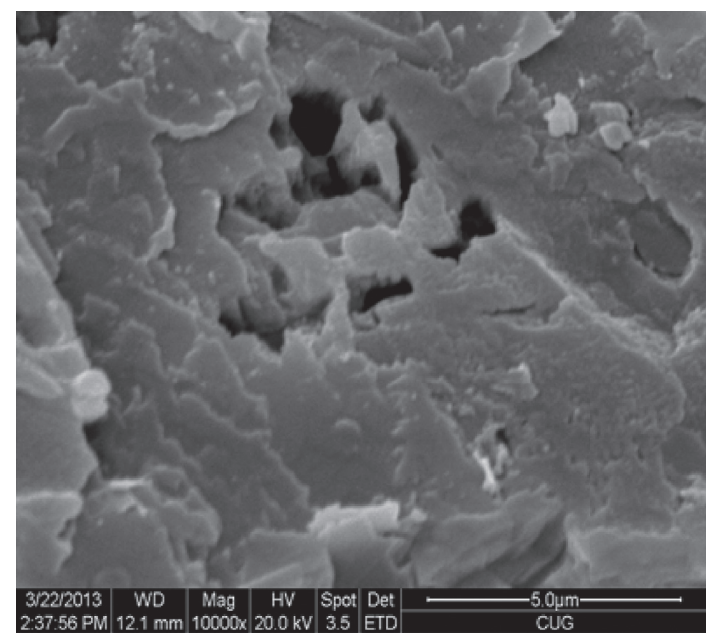

FIGURE 9: Intragranular dissolution pores of carbonaceous rocks.

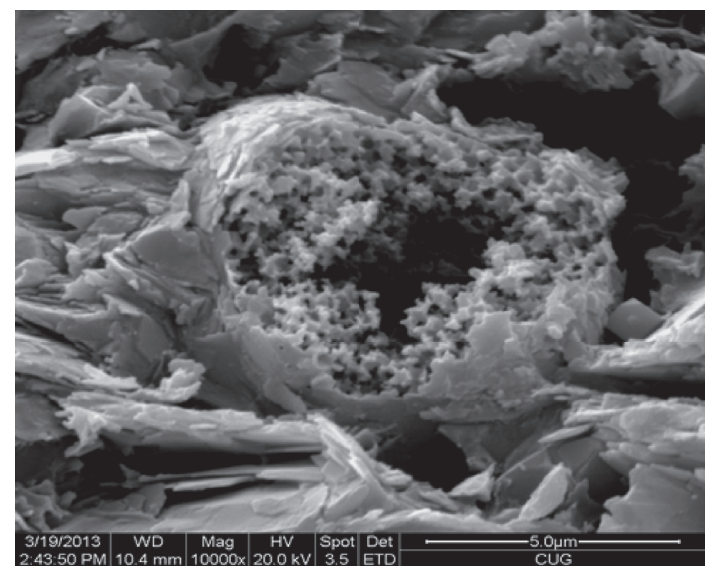

Figure 10: Organic pores in carbonaceous rocks.

These pores provide certain storage space for shale gas generated by organic matter degradation. It also provides a channel for the migration of active fluids such as groundwater. The higher the content of such pores is, the easier the carbonaceous shale can be oxidized to collapse and collapse under the condition of exposed surface.

The study shows that organic matter pores can be produced when the maturity of organic matter in carbonaceous shale is greater than $0.6 \%$. This kind of pore is greatly influenced by the organic carbon content and maturity of shale and increases with the increase of organic carbon content and maturity. However, when the maturity of shale is increased to a certain extent, the microscopic pores and specific surface of shale can be reduced by more than $2.4 \%$. The porosity and adsorption capacity of shale decreased.

3.4. Effect of Cracks on Disintegration Characteristics. According to the size of fractures, they are divided into microcracks and macrofractures. The macrofractures are mainly structural fractures, diagenetic contraction joints, and interlayer foliage joints, which extend relatively far away (Figure 11). Microfracture is mainly developed in the edge of 


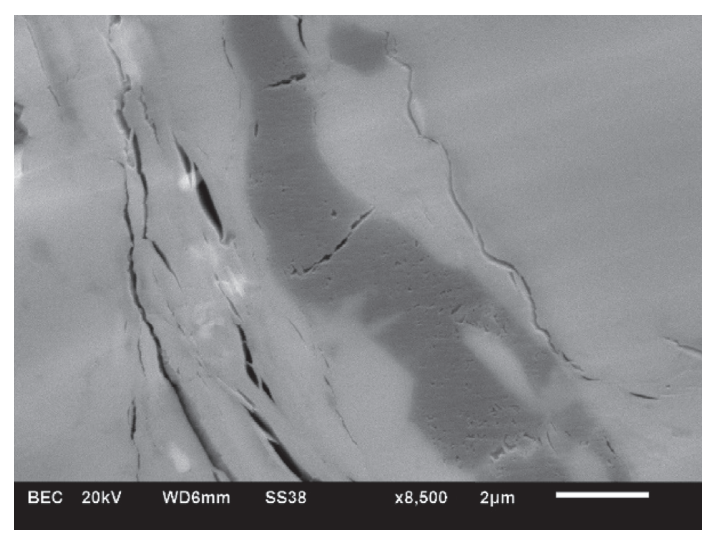

FIGURE 11: Microfracture between clay minerals of carbonaceous shale in the Luofu formation.

brittle mineral grains and clay mineral particles, is mostly serrated and linear, and has good connectivity. The channels that can migrate in the reservoir, such as active fluid and gas, are generally only a few tens of nanometers, with a length ranging from micron to millimeter. In addition, when the brittle mineral particles such as quartz are exposed to stress, the edges are prone to cracks, forming grain edge microfracture. Intergranular microfracture is developed between flake clay minerals, and the fractures extend by $2 \sim 10 \mathrm{~m}$. The cracks are partly filled with calcite, occasionally with a small amount of pyrite and siderite.

It should be noted that, although the above microfractures are not very far away, because of the large quantity and enrichment distribution, the pore permeability conditions of carbonaceous shale often change greatly, especially in the development of underground fluids and other active fluids. They will have a great influence on the weathering and collapse of carbonaceous mud sheets.

In general, the samples of the Devonian Carboniferous carbonaceous shale are mainly composed of mineral pores, organic pores, and microfractures, which are dominated by mineral pores, belonging to micron-sized pores and generally developed pores. The most developed pore types in mineral pores are intragranular dissolved pores, followed by mineral intergranular pores and a small amount of intergranular dissolution pores. The intergranular pores in mineral grains are mostly residual intergranular pores. Their morphology is mostly irregular and slit shaped due to compaction. There are more cloth disposed at the boundary of lamellar, flaky, plate columnar, long columnar rigid minerals, and soft plastic minerals. The connectivity is poor. The microfracture caused by the deformation of the sedimentary structure and brittle minerals is more developed in the local layer, and the seam width is between several tens of nanometers and several microns.

3.5. Porosity and Permeability of Carbonaceous Rocks. The porosity and permeability of carbonaceous shale samples in the test section of the Devonian Carboniferous section and the shale gas geological survey well were collected and summarized. The characteristics of each segment are as follows.
It can be seen from Table 2 that the black shale of the Devonian Luofu formation has a wide porosity range of $0.81 \% \sim 6.90 \%$, a permeability range of $0.0012-0.056 \mathrm{mD}$, an average of $0.0095 \mathrm{mD}$, an average porosity of $1 \%$ in the upper part of the Luofu formation, an average permeability of $0.21 \mathrm{mD}$, an average porosity of the lower member of the Luofu Group, and an average permeability $0.66 \mathrm{mD}$.

\section{Influence of Geochemical Characteristics of Carbonaceous Rocks on Engineering Properties}

\subsection{Mineral Composition and Influence Analysis of Carbonaceous Rocks}

4.1.1. Mineral Composition of Carbonaceous Rocks. Because different types of minerals are different in basic physical properties such as heat dehydration, water swelling, and porosity development, mineral composition analysis is the basis for studying the classification of carbonaceous rocks and analyzing the disintegration of carbonaceous rock slope. The minerals in carbonaceous shale include clay minerals, quartz, calcite, dolomite, Xie Changshi, potash feldspar, siderite, pyrite, and a small amount of sulfate rock.

Minerals have a significant effect on the engineering properties of carbonaceous rocks. Quartz, feldspar, calcite, dolomite, siderite, and pyrite are brittle minerals. The higher their content is, the more brittle the rock is and the more susceptible it is to external forces, resulting in a series of structural fissures. The quartz is mainly derived from terrigenous clasts and biotic siliceous shells. During the diagenesis process, quartz minerals can also be formed. They usually appear in the form of the self-form crystal, which enhances the strength of carbonaceous rocks. Carbonate minerals are mainly calcite, usually in the form of eutectic crystals or filled with cementation. In addition, dolomite, siderite, and manganese carbonate are also found. The feldspar of carbonaceous rocks is mainly derived from terrigenous clasts. Feldspar minerals are usually replaced by clay minerals due to the alteration of diagenesis and alteration. Besides main minerals, pyrite, siderite, and other authigenic minerals are also common in carbonaceous rocks, and their contents are usually low $(<5 \%)$. However, some layers of slope basin facies deposits are more enriched in the deeper water shelf, and sometimes they can form ribbons with pyrite as the main mineral. Later oxidation may cause greater damage to the carbonaceous rock slope. Clay minerals refer to watercontaining layered structure. Mudstone is mainly composed of silicate minerals, the main components are kaolinite, montmorillonite, and illite. It is a hydrophilic mineral, which has a significant effect on the disintegration characteristics of carbonaceous rocks. The higher the hydrophilic mineral content, the stronger the disintegration.

The mineral composition of carbonatite in the Luofu formation is analyzed, as shown in Figure 12 and Table 3. The main mineral components are clay minerals, quartz, 
TABle 2: Physical properties of carbonaceous shale in different areas of Northern Guangxi.

\begin{tabular}{|c|c|c|c|c|c|}
\hline \multirow{2}{*}{ Number } & \multirow{2}{*}{ Horizon } & \multicolumn{2}{|c|}{ Porosity } & \multicolumn{2}{|c|}{ Permeability (mD) } \\
\hline & & Range value (\%) & Average value (\%) & Range value & Average value \\
\hline $1-\mathrm{a}$ & Upper part & $0.06 \sim 2.61$ & 1.0 & $0.03 \sim 5.21$ & 0.21 \\
\hline $1-b$ & Lower part & $0.06 \sim 2.61$ & 0.77 & $0.03 \sim 5.21$ & 0.66 \\
\hline 2 & Luofu group & $0.81-6.90$ & 2.69 & $0.0012-0.056$ & 0.0095 \\
\hline
\end{tabular}

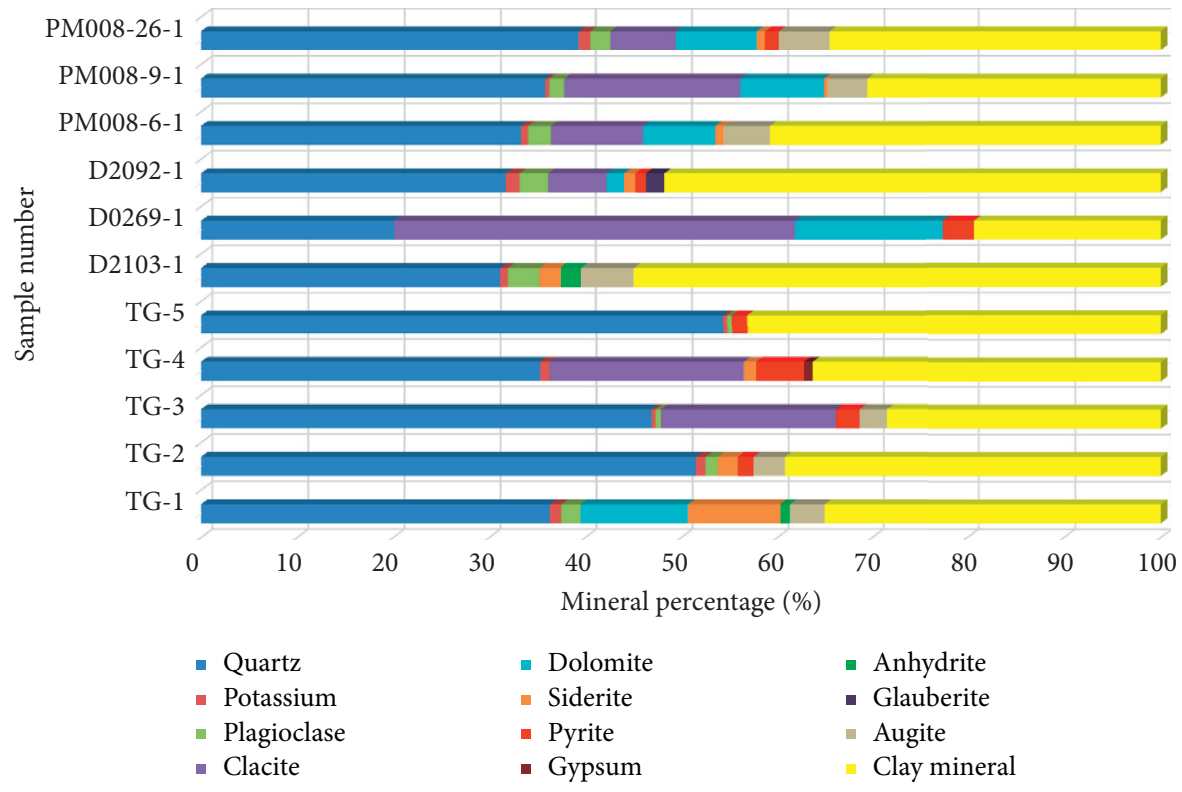

Figure 12: Mineral composition map of carbonaceous shale in Luofu formation, Luofu section, Nandan county.

TABLE 3: Clay mineral composition characteristics of carbonaceous shale in the Luofu formation.

\begin{tabular}{|c|c|c|c|c|c|c|c|c|c|}
\hline $\begin{array}{l}\text { Sample } \\
\text { number }\end{array}$ & Lithology & $\begin{array}{l}\text { Kaolinite } \\
\text { (\%) }\end{array}$ & $\begin{array}{c}\text { Chlorite } \\
(\%)\end{array}$ & $\begin{array}{l}\text { Illite } \\
(\%)\end{array}$ & $\begin{array}{c}\text { Montmorillonite } \\
(\%)\end{array}$ & $\begin{array}{c}\text { Illite/ } \\
\text { montmorillonite } \\
\text { layer }\end{array}$ & $\begin{array}{c}\text { Green/ } \\
\text { montmorillonite } \\
\text { layer }\end{array}$ & & $\begin{array}{l}\text { xed } \\
\text { yer } \\
\text { tio } \\
\end{array}$ \\
\hline- & - & $\mathrm{K}$ & $\mathrm{C}$ & $\mathrm{I}$ & $S$ & $\mathrm{I} / \mathrm{S}$ & $\mathrm{C} / \mathrm{S}$ & $\mathrm{I} / \mathrm{S}$ & $\mathrm{C} / \mathrm{S}$ \\
\hline D2092-1 & \multirow{5}{*}{$\begin{array}{l}\text { Carbonaceous } \\
\text { mudstone }\end{array}$} & - & 11 & 42 & - & 46 & 1 & 5 & 13 \\
\hline PM08-6-1 & & - & 5 & 41 & - & 54 & - & 5 & - \\
\hline PM08-9-1 & & - & 3 & 49 & - & 48 & - & 5 & - \\
\hline $\begin{array}{l}\text { PM08-26- } \\
1\end{array}$ & & - & 3 & 45 & - & 52 & - & 5 & - \\
\hline D0269-1 & & - & - & 32 & - & 68 & - & 5 & - \\
\hline
\end{tabular}

calcite, and dolomite. The highest content of clay minerals is $35.6 \%$, followed by quartz minerals, with an average content of $32.70 \%$, and the content of carbonate minerals is generally low, with an average content of $27.8 \%$. The content of calcite and dolomite in the more calcareous layers can increase to $25 \%-32 \%$, and a small amount of reductive minerals, such as pyrite, siderite, ilmenite, and iron ore, can be seen in the rest. From the composition of clay minerals, kaolinite and montmorillonite are not found, and illite and illite/montmorillonite are the main ones, indicating that the Luofu formation is in the late stage of diagenesis.
4.1.2. Water Swelling of Carbonaceous Clay Minerals. The main mineral components in carbonaceous shale samples are clay minerals and quartz. Clay minerals are a kind of silicate or aluminosilicate, which can be divided into two types: amorphous and crystalline. The latter can be divided into two different structural types: lamellar and chain stratiform. One is the repeated stacking of the same type of clay mineral structural units, which are called simple layered clay minerals, such as kaolinite, halloysite, montmorillonite, illite, and chlorite. The other is made up of two or more than two types of clay mineral structural units called mixed layer clay minerals. It can be further divided into two 
types: ordered mixed layer and disorder mixed layer. Besides layered and chain layered clay minerals, there are also amorphous and semicrystalline clay minerals, such as hydrargillite, and hairy stripe. They are less distributed in clay rock.

It should be specially pointed out that there is a certain pore between the structural units of clay minerals, which often fills with more water molecules or other hydration cations. This layered structure determines their water sensitivity, and the adsorbed water and interlayer water content of different minerals are different.

Clay minerals have strong water absorption ability. They are the manifestation of hydration of clay minerals. Previous studies have shown that hydration of clay minerals can be divided into two stages. The first stage is hydration of clay adsorbed by exchanged cation. The second stage is hydration between clay minerals at the crystal level. In clay minerals, the hydration capacity of montmorillonite is the strongest and hydration volumetric expansion can exceed 50\%. The hydration of some sodium montmorillonite can increase 8-10 times the volume of the dry soil. The reason is that the molecular structure of the montmorillonite crystal structure is linked by molecular attraction, and the bond force is weak. The water molecules can easily enter the structural layer along the silicon oxygen layer so that the adjacent lamellar bodies are separated and the spacing between layers increases, thus causing the volume to expand. The cation absorbed by montmorillonite $\left(\mathrm{Na}^{+}\right.$and $\left.\mathrm{Ca}^{2+}\right)$ will form thicker hydration film on the surface of montmorillonite, which will increase the cell distance and expand the volume. Besides montmorillonite, the water absorption and expansion of illite and halloysite are next, and kaolinite is the weakest. Besides, clay minerals contain a large amount of intragranular dissolution pores and intergranular pores. It also provides a certain physical space for mineral water swelling. These clay minerals often affect the formation of plastic deformation, such as landslides, rock disintegration, and other geological disasters.

From the Devonian carbonaceous rocks sampled from the investigation, it is concluded that the clay minerals are mainly illite and illite/montmorillonite mixed layer and a small amount of kaolin and chlorite are found in the clay layer. The content of montmorillonite and other minerals is relatively small. Therefore, the illite and illite/illite mixed layer are the decisive factors for the water swelling of these carbonaceous rocks.

4.1.3. Thermal Dehydration of Clay Minerals. The thermal dehydration of clay minerals is the phenomenon that the clay minerals lose the interlayer water and structural water when heated to a certain extent. According to the data research, the temperature of different clay minerals is quite different from that of thermal dehydration. Kaolinite starts to lose structural water between heating $400^{\circ} \mathrm{C} \sim 525^{\circ} \mathrm{C}$ and has no significant dehydration phenomenon below $400^{\circ} \mathrm{C}$ and upper $550^{\circ} \mathrm{C}$; below $400^{\circ} \mathrm{C}$ and even below $100^{\circ} \mathrm{C}$, some interlayer water has been dehydrated. The main dehydration stage at $400^{\circ} \mathrm{C} \sim 500^{\circ} \mathrm{C}$ is mainly the interlayer water and structural water. Some of the structural water has been deactivated until $800^{\circ} \mathrm{C}$. Because of a large amount of interlayer water, montmorillonite has started to remove some interlayer water at $0^{\circ} \mathrm{C} \sim 100^{\circ} \mathrm{C}$, and then lost a lot of interlayer water at about $100^{\circ} \mathrm{C} \sim 350^{\circ} \mathrm{C}$. At $300^{\circ} \mathrm{C} \sim 600^{\circ} \mathrm{C}$, the structure water is mainly lost. When the illite is heated, it will first lose the adsorbed water and interlayer water below 100 degrees. After that, it is mainly the stage of structural water loss at $200^{\circ} \mathrm{C} \sim 500^{\circ} \mathrm{C}$.

According to the results of previous rock mineral tests, the clay minerals in the Guangxi Devonian Carboniferous carbonaceous shale samples were mainly illite, which belonged to rock types which were more susceptible to thermal dehydration. In addition, the fresh surface of carbonaceous shale was mainly black, and it was easier to absorb and store heat under the sun's illumination, thus increasing the temperature of the rock. The destruction of rock formations and the long summer time and sufficient illumination in Guangxi will cause the collapse of these carbonaceous shale slopes in a relatively short period of time due to continuous heat and dehydration.

It can be concluded that carbonaceous shale can produce a series of mechanical deformation, forming a series of cracked fissures, cracks, and so on, due to the influence of the swelling and shrinkage of the clay minerals and the heat and dehydration of the sun when exposed to the surface.

\subsection{Geochemical Characteristics and Influence Analysis of Organic Matter}

4.2.1. Abundance of Organic Matter. Organic matter in rocks is a residual organism that is deposited and retained in rocks in relatively reduced, blocked, or deeper water environments. Organic matter is the material basis for hydrocarbon generation of shale gas. Its abundance determines the hydrocarbon generation and expulsion ability of carbonaceous shale. The abundance of organic matter is mainly evaluated by parameters such as total organic carbon (TOC), hydrocarbon generation potential $(s 1+s 2)$, and chloroform green "a." The total organic carbon (TOC) is an important reference standard for the abundance of organic matter. In particular, it has strong adaptability to marine organic shale. According to the technical specification for calculation and evaluation of shale gas resources/reserves, the TOC content of carbonaceous rocks is divided into 5 grades: high $(>4 \%)$, high $(2 \% \sim 4 \%)$, medium (1\% 2\%), low $(0.5 \% \sim 1 \%)$, and ultralow $(<0.5 \%)$.

The carbonaceous shale with high organic matter content is easier to disintegrate or produce other deformation due to oxidation and decomposition of organic matter and reducing minerals. Therefore, it is necessary to test and analyze the content and type of TOC in carbonaceous rock slope. TOC test results of carbonaceous shale in the Middle Devonian Luofu formation are shown in Table 4:

According to Table 4, the carbonaceous shale TOC of the Luofu Group is $0.11 \% \sim 0.81 \%$ (mean $0.37 \%$ ) in Che $\mathrm{He}$ Town, Nandan, and the Nandan Dachang is $0.54 \% \sim 4.74 \%$ (mean 3.14\%), and the area changes greatly. This 
TABLE 4: TOC statistics of carbonaceous shale in the Middle Devonian Luofu formation.

\begin{tabular}{lccccc}
\hline Group class & Sampling position & Minimum (\%) & Max (\%) & Average (\%) & Number of samples \\
\hline \multirow{2}{*}{ Luofu group } & Che He town, Nandan & 0.11 & 0.81 & 0.37 & 6 \\
& Nandan Dachang & 0.54 & 4.74 & 3.14 & 14 \\
\hline
\end{tabular}

phenomenon is mainly attributed to the sedimentary pattern of the interbasin facies in the central Guizhou depression, and the sedimentary facies change rapidly in space. The difference of the organic matter source leads to the larger heterogeneity of TOC in space. The content of TOC is relatively high in the center of the basin with relatively reduced block and deep water, and the TOC content of the carbonaceous rocks near the edge of the basin is relatively low.

4.2.2. Effects of Different Organic Matter Types. The type of organic matter largely determines the stability of carbonaceous rocks. Different organic matter types have different source of material, sedimentary environment, rock composition, and structure, so the potential for further decomposition is also quite different. The damage caused by oxidative decomposition to rock stability is also very different under the condition of surface exposure. By using kerogen macerals test to determine the parent material types of organic matter, combined with previous research results, the types of kerogen in the investigation area are discriminated. The classification criteria are shown in Table 5. Kerogen microconstituents are small and difficult to distinguish under microscope. Therefore, the determination of organic matter is mainly based on the data of borehole sample and typical section data of shale gas geology survey.

According to the results of Table 6, Luofu group, the maceral of kerogen is mainly composed of Sao mud group. The content of the kerogen is $59.3 \% \sim 87.7 \%$, while the vitrinite content is only $12.0 \% \sim 40.7 \%$. The content of the inert group is almost 0 . The total organic matter is type $\mathrm{II}_{1}$, and only a few samples are type $\mathrm{II}_{2}$ organic matter.

Therefore, the total average value of TOC (total organic matter content) in the carbonaceous rock samples sampled is over $1 \%$. It belongs to the carbonaceous rocks of medium high source rocks and has higher organic matter content. In terms of organic matter type, the organic matter in carbonaceous shale mainly consists of type $\mathrm{I}$ and $\mathrm{II}_{1}-\mathrm{II}_{2}$, which has higher hydrocarbon generating potential and has great potential for oxidation and decomposition under natural exposure. The organic matter in siliceous mudstone, carbonaceous calcareous mudstone, and carbonaceous mudstone is dominated by type III, which is less hydrocarbon generating potential. It is not easy to cause further oxidative decomposition. Therefore, carbonaceous shale is more prone to rock disintegration and collapse than other rocks. In addition, for the fresh rock samples in core, the TOC content of the semiweathered rock samples in the surface section is relatively low. It should be related to the weathering and decomposition loss of organic matter in carbonaceous shale.
4.2.3. Oxidation and Decomposition of Organic and Reductive Minerals. Carbonaceous shale is mainly formed in the lagoon, swamp, bay, and deep water slope, basin of block reduction, quiet and low energy, rich in massive reductive metal sulfide such as reduced organic matter and pyrite. Under the condition of natural exposure, they will undergo oxidative decomposition reaction under the combined action of oxygen and water, thus causing certain damage to the structure of the rock.

In Section 4, the total average value of TOC (total organic matter content) in the Devonian Carboniferous carbonaceous rocks sampled is more than $1 \%$. It belongs to carbonaceous rocks of medium high source rocks and has higher organic matter content. In terms of organic matter type, organic matter in carbonaceous shale is mainly composed of rotten mud group, mostly unsaturated alkanes and biomarkers. They are prone to react with oxygen and water under the action of certain microorganisms, releasing $\mathrm{CO}_{2}$ and heat, resulting in more fluffy or plastic deformation due to oxidation and $\mathrm{CO}_{2}$ release, and resulting in rock disintegration and collapse.

Pyrite and other reducing minerals are common metal sulphides in black carbonaceous shale. They are often locally enriched into ribbons, pellets, etc., which are easily reacted with air, water, and other media. After reaction, hydrogen ions can be generated to make the solution acidified, while the oxidation of sulphide ions and iron ions can react with other minerals in the reaction water solution and surrounding rocks. A series of weathering products which affect the engineering properties of carbonaceous rock slopes have been generated. Previous studies have found that [17] the oxidation processes of pyrites can be divided into two distinct processes: pure chemical oxidation and microbial oxidation.

The oxidation of pyrite is mainly due to Thiobacillus ferrooxidans, which can oxidize $\mathrm{Fe}^{2+}$, S elements, $\mathrm{H}_{2} \mathrm{~S}$, and other inorganic components, and belongs to autotrophic aerobic acidophilic bacteria. However, the reaction must take place on the surface of microbiological bacteria and sulfide mineral crystals. The reaction equation is $\mathrm{FeS}_{2}+7 /$ $2 \mathrm{O}_{2}+\mathrm{H}_{2} \mathrm{O} \longrightarrow \mathrm{Fe}^{2+}+2 \mathrm{SO}_{4}^{2-}+2 \mathrm{H}^{+}$.

The oxidants for chemical oxidation of pyrite under natural exposure are usually $\mathrm{O}_{2}$ and $\mathrm{Fe}^{3+}$, and their oxidation steps are similar to biological oxidation pathways. The first step is the dissolution oxidation reaction of pyrite with dissolved oxygen and water so that the iron element in the mineral lattice of pyrite is precipitated into ferrous ions, and sulfur is oxidized to form sulfate ion (1). In the second step, the generated ferrous ions are further oxidized by dissolved oxygen to form iron ions (2). In the third step, the ferric ions produced reaction with pyrite, which gradually oxidizes sulfur in pyrite to elemental sulfur and sulfate ions, and iron ions are reduced to ferrous ions (3) and (4). In the fourth 
TABLE 5: List of kerogen types for classification of kerogen (sy/t5735-1995 three, four divisions).

\begin{tabular}{|c|c|c|c|c|c|}
\hline \multicolumn{2}{|c|}{ Type } & Type I (rotten clay type) & $\mathrm{II}_{1}$ (rotten rot type) & $\mathrm{II}_{2}$ (rotten mud rot type) & III (rot type) \\
\hline \multirow{3}{*}{ Kerogen inspection } & Chitin group (\%) & $70 \sim 90$ & $70 \sim 50$ & $50 \sim 10$ & $<10$ \\
\hline & Vitrinite group (\%) & $<10$ & $10 \sim 20$ & $20 \sim 70$ & 70 90 \\
\hline & TI & $80 \sim 100$ & $80 \sim 40$ & $40 \sim 0$ & $<0$ \\
\hline
\end{tabular}

TABle 6: Macerals and organic matter types of carbonaceous kerogen in the Nandan Dachang section of the Luofu formation.

\begin{tabular}{|c|c|c|c|c|c|c|c|c|}
\hline \multirow{2}{*}{ Region } & \multirow{2}{*}{ Horizon } & \multirow{2}{*}{ Lithology } & \multicolumn{4}{|c|}{ Macerals (\%) } & \multirow{2}{*}{ Type index } & \multirow{2}{*}{ Type } \\
\hline & & & Sapropelite & Chitin group & Vitrinite group & Inert group & & \\
\hline Nandan & $\mathrm{D}_{2} \mathrm{l}$ & Gray-black carbonaceous mudstone & 60.0 & 0.0 & 40.0 & 0.0 & 30.0 & $\mathrm{II}_{2}$ \\
\hline Nandan & $\mathrm{D}_{2} \mathrm{l}$ & Gray-black carbonaceous mudstone & 69.3 & 0.0 & 30.3 & 0.3 & 46.3 & $\mathrm{II}_{1}$ \\
\hline Nandan & $\mathrm{D}_{2} \mathrm{l}$ & Gray-black carbonaceous mudstone & 75.3 & 0.0 & 24.0 & 0.7 & 56.6 & $\mathrm{II}_{1}$ \\
\hline Nandan & $\mathrm{D}_{2} \mathrm{l}$ & Gray-black carbonaceous mudstone & 59.3 & 0.0 & 40.7 & 0.0 & 28.8 & $\mathrm{II}_{2}$ \\
\hline Nandan & $\mathrm{D}_{2} \mathrm{l}$ & Gray-black carbonaceous mudstone & 81.7 & 0.0 & 18.3 & 0.0 & 68 & $\mathrm{II}_{1}$ \\
\hline Nandan & $\mathrm{D}_{2} \mathrm{l}$ & Gray-black carbonaceous mudstone & 83.0 & 0.0 & 17.0 & 0.0 & 70.3 & $\mathrm{II}_{1}$ \\
\hline Nandan & $\mathrm{D}_{2} \mathrm{l}$ & Gray-black carbonaceous mudstone & 83.3 & 0.0 & 16.3 & 0.3 & 70.8 & $\mathrm{II}_{1}$ \\
\hline Nandan & $\mathrm{D}_{2} \mathrm{l}$ & Gray-black carbonaceous mudstone & 60.0 & 0.0 & 39.0 & 1.0 & 29.8 & $\mathrm{II}_{2}$ \\
\hline Nandan & $\mathrm{D}_{2} \mathrm{l}$ & Gray black carbonaceous mudstone & 71.0 & 0.0 & 28.3 & 0.7 & 49.1 & $\mathrm{II}_{1}$ \\
\hline Nandan & $\mathrm{D}_{2} \mathrm{l}$ & Gray-black carbonaceous mudstone & 80.3 & 0.0 & 19.3 & 0.3 & 65.5 & $\mathrm{II}_{1}$ \\
\hline Nandan & $\mathrm{D}_{2} \mathrm{l}$ & Gray-black carbonaceous mudstone & 87.7 & 0.0 & 12.0 & 0.3 & 78.4 & $\mathrm{II}_{1}$ \\
\hline Nandan & $\mathrm{D}_{2} \mathrm{l}$ & Gray-black carbonaceous mudstone & 75.3 & 0.0 & 24.0 & 0.7 & 56.6 & $\mathrm{II}_{1}$ \\
\hline Nandan & $\mathrm{D}_{2} \mathrm{l}$ & Gray-black carbonaceous mudstone & 85.3 & 0.0 & 14.0 & 0.3 & 74.5 & $\mathrm{II}_{1}$ \\
\hline
\end{tabular}

step, some sulphuric acid ferric ions are hydrolyzed to form basic sulphuric acid ferric (5):

$$
\begin{gathered}
2 \mathrm{FeS}_{2}+7 \mathrm{O}_{2}+2 \mathrm{H}_{2} \mathrm{O} \longrightarrow 2 \mathrm{FeSO}_{4}+2 \mathrm{H}_{2} \mathrm{SO}_{4} \\
\mathrm{FeSO}_{4}+\mathrm{O}_{2}+2 \mathrm{H}_{2} \mathrm{SO}_{4} \longrightarrow 2 \mathrm{Fe}_{2}\left(\mathrm{SO}_{4}\right)_{3}+2 \mathrm{H}_{2} \mathrm{O} \\
\mathrm{Fe}_{2}\left(\mathrm{SO}_{4}\right)_{3}+\mathrm{FeS}_{2} \longrightarrow 3 \mathrm{FeSO}_{4}+2 \mathrm{~S} \\
6 \mathrm{Fe}_{2}\left(\mathrm{SO}_{4}\right)_{3}+2 \mathrm{~S}+8 \mathrm{H}_{2} \mathrm{O} \longrightarrow 12 \mathrm{FeSO}_{4}+8 \mathrm{H}_{2} \mathrm{SO}_{4} \\
\mathrm{Fe}_{2}\left(\mathrm{SO}_{4}\right)_{3}+2 \mathrm{H}_{2} \mathrm{O} \longrightarrow 2 \mathrm{Fe}(\mathrm{OH}) \mathrm{SO}_{4}+\mathrm{H}_{2} \mathrm{SO}_{4}
\end{gathered}
$$

Generally speaking, the initial reaction solution of pyrite oxidation is usually high and the rate of oxidation is slower. With the continuous reaction, the hydrogen ion generated by pyrite oxidation reduces the solution value. When the duty drop is less than 2.5 , the solubility of iron ion hydrolysates will increase significantly, and the reactivity of iron ions will be significantly enhanced, resulting in the rapid oxidation of pyrite. The oxidation and hydrolysis of pyrite will change the original $\mathrm{pH}$ value of rock and then destroy the structure of strata, resulting in collapse, collapse, and so on.

To sum up, the collapse of carbonaceous rock slope is the result of many factors. Therefore, when carbonaceous rock slope treatment and ecological rehabilitation are carried out, we should make full investigation and comprehensive analysis and evaluation before making reasonable and effective treatment methods.

\section{Conclusion}

Through comprehensive field investigation, the main distribution horizon, outcropping area, and lithological combination characteristics of carbonaceous rocks in Guangxi area are identified. The influence of the microscopic pore types and geochemical characteristics of carbonaceous rocks on the engineering characteristics is studied in combination with the rock samples analysis and test results. The main cause and mechanism of carbonaceous rock disintegration are obtained. The main conclusions are as follows:

(1) Through the investigation of carbonaceous rocks in Guangxi China, it is concluded that carbonaceous rocks are distributed in the Luofu formation of the Devonian system, the Luzhai formation of the Carboniferous system, and the Qingxi formation of the Cambrian. They are mainly formed in the depositional environment of deep water basin, slope, and confined coastal lagoon and swamp, which belong to the tectonic weak layer. It is more prone to produce various types of folds, faults, joints, cleavages, cracks, and other structural deformation and a series of structural weak surfaces, which affect the stability of carbonaceous rock slopes.

(2) Scanning electron microscope (SEM) was used to study the mineral pores, organic matter pores, and the microstructure of cracks in carbonaceous rocks. Mineral intergranular pores were mostly residual intergranular pores. There were more cloth disposed at the boundary of lamellar, flaky, plate columnar, long columnar rigid minerals, and soft plastic minerals. The connectivity is poor. The higher the pore content of organic matter is, the more easily the carbon shale is exposed to the surface. The microfracture caused by the deformation of the sedimentary structure and brittle minerals is more developed in the local layer. The porosity of the black shale in the Devonian Luofu formation is 
$0.81 \% \sim 6.90 \%$, with an average of $2.69 \%$, and the permeability range is $0.0012-0.056 \mathrm{mD}$, with an average of $0.0095 \mathrm{mD}$.

(3) The engineering properties of carbonaceous rocks are related to the oxidation and decomposition of mineral composition, organic matter, and reductive minerals. The clay minerals in carbonaceous rocks are mainly illite and illite/montmorillonite layers, which have the characteristics of water swelling and heat dehydration. They are prone to crevice under the condition of exposure to the surface and break down. The total average value of TOC (total organic matter content) of carbonaceous rock is above $1 \%$. The type $\mathrm{I}$ and $\mathrm{II}_{1}-\mathrm{II}_{2}$ with large hydrocarbon generating potential is the main type, which has great potential for oxidation and decomposition under the condition of natural exposure, and the oxidative hydrolysis of pyrite will change the original $\mathrm{PH}$ value of rock, which will cause rock collapse and collapse.

\section{Data Availability}

The data used to support the findings of the study are available from the corresponding author upon request.

\section{Conflicts of Interest}

The authors declare that there are no conflicts of interest regarding the publication of this paper.

\section{Acknowledgments}

This study was supported by the Science and Technology Project of Guangxi "Research on the Key Technologies of highway construction in Guangxi carbonaceous rock area" (Grant GuikeAC16380119) and "Research and Application of ecological slope protection technology in carbonaceous rock slope" (Grant AD19110124).

\section{References}

[1] J. H. Luo, D. C. Mi, Q. Y. Ye, G. H. Sun, and D. Q. Chen, "Study on microscopic characteristics and physical and mechanical parameters of carbonaceous rocks," Materials Science Forum, vol. 980, pp. 368-376, 2020.

[2] T. Zhang, Y. L. Yang, and S. Y. Liu, "Application of biomass by-product lignin stabilized soils as sustainable Geomaterials: a review," Science of the Total Environment, vol. 728, Article ID 138830, 2020.

[3] J. H. Luo, D. C. Mi, H. F. Huang, T. Zhang, G. H. Sun, and D. Q. Chen, "Intelligent monitoring, stability evaluation, and landslide treatment of a carbonaceous mudstone and shale slope in Guangxi, China," International Journal of Safety and Security Engineering, vol. 10, no. 3, pp. 373-379, 2020.

[4] B. Yin, Rock Formation in Guangxi Zhuang Autonomous Region, China University of Geosciences Press, Beijing, China, 1997.

[5] W. Guo, "Geological conditions for shale gas accumulation and favorable area prediction of Luofu formation of devonian in Tian'e-Nandan area," Petroleum Geology and Engineering, vol. 32, no. 1, pp. 22-26, 2018.
[6] C. Zhang, X. Liu, and S. Xu, "The characteristics of organic rich shale in inter-platform basin-a case study on Luofu formation from mode cross section in Nandan," Mineralogy and Petrology, vol. 37, no. 1, pp. 84-92, 2017.

[7] B. Wang, "Evaluation of organic matter maturity of marine carbonaceous shale by aromatics-take luofu formation of devonian as an example," in Proceedings of the 12th National Congress of the Palaeontological Society of China (PSC) and the 29th Annual Conference of PSC, Zhengzhou, China, 2018.

[8] Z. Zhang, J. Wei, and D. Shi, "Shale gas characteristics of organic-rich shale in Luofu formation in guizhong depression," Petroleum Geology \& Experiment, vol. 41, no. 1, pp. 16-22, 2019.

[9] Y. Kun, F. Xin-xin, L. Tuo, B. Shu-jing, S. Di-shi, and Z. Cong, "Geochemical features and sedimentary conditions of middledevonian shale in the northwestern central-Guangxi depression," Geology and Exploration, vol. 53, no. 1, pp. 01790186, 2017.

[10] W. Guo, C. Zhang, and X. Wang, "Element geochemical characteristics of the middle ordovician shale in tian'eNandan of northwestern Guangxi and its significance," Yunnan Chemical Technology, vol. 44, no. 8, pp. 112-114, 2017.

[11] Y. Pan, M. Zhi-chao, and L. Xiao-lin, "Oganic geochemical characteristics and geological significance of shale source rocks from Luofu formation of devonian in northwestern Guangxi," Science Technology and Engineering, vol. 16, no. 35, pp. 52-58, 2016.

[12] L. Zeng, J. X. Lou, and J. C. LiuWu, "Carbonaceous mudstone and lignin-derived activated carbon and its application for supercapacitor electrode," Surface and Coatings Technology, vol. 357, pp. 580-586, 2019.

[13] D. Chen, J. Luo, X. Liu, D. Mi, and L. Xu, "Improved doublelayer soil consolidation theory and its application in marine soft soil engineering," Journal of Marine Science and Engineering, vol. 7, no. 5, p. 156, 2019.

[14] W. Chen, D. Jeng, W. Chen, G. Chen, and H. Zhao, "Seismicinduced dynamic responses in a poro-elastic seabed: solutions of different formulations," Soil Dynamics and Earthquake Engineering, vol. 131, Article ID 106021, 2020.

[15] R. L. Hermanns, S. Niedermann, S. Ivy-Ochs et al., "Rock avalanching into a landslide-dammed lake causing multiple dam failure in Las Conchas valley (NW Argentina)-evidence from surface exposure dating and stratigraphic analyses," Landslides, vol. 1, no. 2, pp. 113-122, 2004.

[16] R. Wang, "Fundamentals of rock mechanics," Engineering Geology, vol. 17, no. 3, 1981.

[17] X. Liao, Study on Weathering Characteristics of Black Shale and Oxidation Kinetics of Pyrite Embedded in Rocks, Southwest Jiaotong University, Chengdu, China, 2013. 